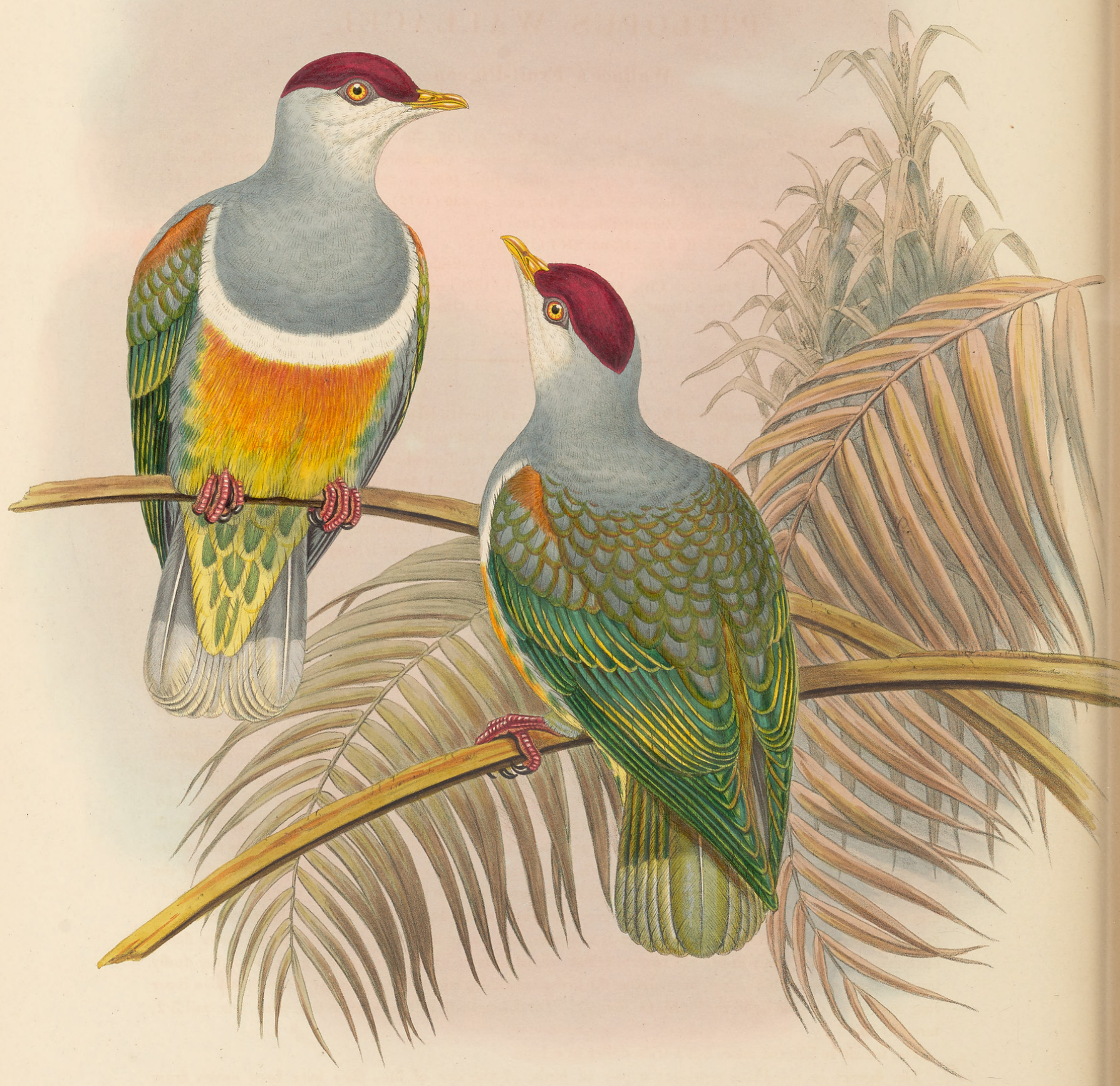




\title{
PTILOPUS WALLACEI.
}

\author{
Wallace's Fruit-Pigeon.
}

Ptilonopus wallacei, Gray, Proc. Zool. Soc. 1858, pp. 185, 195, pl. 136.-Id. Cat. B. New Guinea, pp. 45, 60 (1859).-Id. Proc. Zool. Soc. 1861, p. 437.-Reichenb. Columbariæ, ii. p. 178 (1862).-Rosenb. N. T. Nederl. Ind. xxv. p. 248 (1863).-Wallace, Ibis, 1865, p. 380.-Finsch, Neu-Guinea, p. 177 (1865).-Pelz. Verh. zool.-bot. Gesellsch. Wien, xxii. p. 430 (1872).

Philopus wallacei, Rosenb. Reis. naar Zuidostereil, p. 50 (1867).

Ptilinopus wallacei, Gray, Hand-l. B. ii. p. 227, no. 9154 (1870).

Ptilopus wallacei, Rosenb. Reis. naar Zuidostereil, p. 81 (1867).-Schlegel, Mus. Pays-Bas, Columbæ, p. 18 (1873).-Salvad. Ann. Mus. Civic. Genov. ix. p. 197 (1876)._Elliot, Proc. Zool. Soc. 1878, p. 555.Salvad. Ann. Mus. Civic. Genov. xiv. p. 658 (1879).-Id. Orn. Papuasia, etc. iii. p. 30 (1881).

THis beautiful Pigeon was discorered by Mr. A. R. Wallace in the Aru Islands, where it has also been met with by Dr. Beccari and Baron Von Rosenberg. The last-named naturalist has also observed it on the Ké Islands, and more recently a fine series has been brought from the Tenimber Islands by $\mathrm{Mr}$. H. O. Forbes.

We have carefully compared Mr. Forbes's specimens with the typical Aru-Islands bird and cannot find the slightest difference between them.

This beautiful Pigeon, Mr. Forbes informs us, is very common in the northern portions of the Tenimber group which he visited, frequenting the fig-trees (Urostigma). Its nature is very tame, and numbers of specimens could be easily procured. The native name is "Wofoen Ratoe."

We have described a fine pair of birds collected in the above-named locality by Mr. Forbes.

Adult male. Crown of head, tapering somewhat to a point on the nape, deep crimson, as well as the lores; feathers behind the eye and ear-coverts, sides of neck, hind neck, and mantle delicate French grey; upper back and scapulars mottled, the feathers being delicate French grey, with orange margins ; lesser wing-coverts dull orange, forming a shoulder-patch; median coverts French grey, with broad edgings of yellowish olive; greater series green, inclining to olive-yellow towards the ends and narrowly margined with yellow; bastard wing, primary-coverts, and quills deep grass-green with a bronzy gloss, the inner webs being blue-black; secondaries more olive than the primaries and edged with yellow, the innermost secondaries olive yellowish with grey centres like the greater wing-coverts; remainder of back yellowish green, with more or less of an orange tinge, especially on the upper back, where there is a patch of dull orange; upper tail-coverts and tail yellowish green, dark green towards the base, the terminal half pale greenish ashy, edged externally with yellow and becoming whitish on the inner web ; the ends of the feathers dusky greenish, broader on the centre ones; cheeks, throat, and ear-coverts white, with a faint grey shade on the throat, the upper part of the ear-coverts rather dusky; fore neck and chest pale French grey like the sides of the neck, and forming a band ; breast deep rich orange, separated from the grey chest by a rather broad band of white slightly sullied with grey; abdomen bright yellow; sides of breast, axillaries, and under wing-coverts French grey; lower flanks olive-green; thighs grey; under tail-coverts yellow, edged broadly with green ; quills grey, becoming dusky towards their euds; " bill yellow, but paler on the lower mandible ; legs and feet purple ; iris with golden inner ring and outer one of light red" (H. O. Forbes). Total length 9 inches, culmen $0 \cdot 8$, wing $5 \cdot 9$, tail $3 \cdot 2$, tarsus 0.95 .

The female is like the male, but a trifle duller in colour.

The figures in the Plate represent a pair of birds, of the size of life; they have been drawn from Mr. Forbes's specimens above described. 


\section{$2 \mathrm{BHL}$ Biodiversity Heritage Library}

Gould, John and Sharpe, Richard Bowdler. 1883. "Ptilopus wallacei, Wallace's Fruit-Pigeon [PI. 55]." The birds of New Guinea and the adjacent Papuan islands : including many new species recently discovered in Australia 5(XV), -. https://doi.org/10.5962/p.322899.

View This Item Online: https://www.biodiversitylibrary.org/item/230441

DOI: https://doi.org/10.5962/p.322899

Permalink: https://www.biodiversitylibrary.org/partpdf/322899

\section{Holding Institution}

Smithsonian Libraries

\section{Sponsored by}

Biodiversity Heritage Library

\section{Copyright \& Reuse}

Copyright Status: Public domain. The BHL considers that this work is no longer under copyright protection.

This document was created from content at the Biodiversity Heritage Library, the world's largest open access digital library for biodiversity literature and archives. Visit BHL at https://www.biodiversitylibrary.org. 